\title{
KERAJINAN TANGAN BERBAHAN DASAR KORAN SEBAGAI ALAT PENINGKATAN EKONOMI
}

\section{HANDICRAFTS HANDMADE BASED ON NEWSPAPER AS A TOOL FOR ECONOMIC IMPROVEMENT}

\author{
M A Humaira1a, I Muhdiyati ${ }^{1}$, A S Anggraeni 1 , B Putri ${ }^{1}$, Herul ${ }^{1}$, Lutfia Paujiah ${ }^{1}$, N Fauziah 1, \\ Rahmawati ${ }^{1}$, S Muti'ah ${ }^{1}$, S Fauziah ${ }^{1}$ \\ ${ }^{1}$ Fakultas Keguruan dan Ilmu Pendidikan, Universitas Djuanda Bogor, Jl. Tol Ciawi No.1 Kotak Pos 35 \\ Bogor 16720 Indonesia \\ a'Korespondensi: Anggi Sekar Anggraeni; E-mail: Anggi.sekar@gmail.ac.id \\ (Diterima: 29-11-2018; Ditelaah: 28-11-2018; Disetujui: 23-03-2019)
}

\begin{abstract}
Creative economy is a concept for carrying out sustainable economic development based on creativity. In organizing economic improvements in Kampung Goleah, a new innovation is needed to make the village have a livelihood besides farming and gardening. One effort in improving the economy in Kampung Goleah was by conducting training in making paper-based handicrafts in Kampung Goleah, Sukagalih Village. With the aim of improving the economy of the people in the area, specifically providing assistance to mothers to make a work from a used newspaper. As a result, works made from used newspapers can be sold and improve their economy.
\end{abstract}

Keywords: Creative Economy, Innovation, Mentoring, Newspaper Handicrafts, Training.

\begin{abstract}
ABSTRAK
Ekonomi kreatif merupakan suatu konsep untuk melakukan pembangunan ekonomi yang berkelanjutan berbasis kreativitas. Dalam menyelenggarakan perbaikan perekonomian di Kampung Goleah dibutuhkan suatu inovasi baru yang membuat kampung tersebut memiliki mata pencaharian selain bertani dan berkebun. Salah satu upaya dalam peningkatan perekonomian di Kampung Goleah ialah dengan melakukan pelatihan pembuatan kerajinan tangan berbahan dasar koran di Kampung Goleah Desa Sukagalih. Dengan tujuan meningkatkan perekonomian masyarakat di daerah tersebut, khususnya melakukan pendampingan kepada ibu-ibu untuk membuat sebuah karya dari Koran bekas. Hasilnya, karya yang terbuat dari Koran bekas tersebut dapat dijual dan meningkatkan perekonomian mereka.

Kata kunci: Ekonomi Kreatif, Inovasi, Kerajinan Tangan Koran, Pelatihan, Pendampingan.

Humaniora, M. A., Muhdiyati, I., Anggraeni, A. S., Putri, B., Herul., Paujiah, L., Fauziah, N., Rahmawati., Muti'ah, S., \& Fauziah, S. (2019). Kerajinan Tangan Berbahan Dasar Koran Sebagai Alat Peningkatan Ekonomi. Jurnal Qardhul Hasan: Media Pengabdian kepada Masyarakat, 5(1), 46-56.
\end{abstract}




\section{PENDAHULUAN}

Universitas Djuanda (UNIDA) Bogor merupakan salah satu Perguruan Tinggi Swasta yang terletak di Kabupaten Bogor Kecamatan Ciawi yang memiliki peran dalam meningkatkan bidang penelitian maupun pengabdian kepada masyarakat. Untuk hal tersebut, kami memfokuskan pada kegiatan pengabdian kepada masyarakat pada salah satu bidang ekonomi dengan membawa program kerja ekonomi kreatif ke Desa Sukagalih, Kampung Goleah, Kecamatan Megamendung, Kabupaten Bogor.

Peningkatan perekonomian adalah suatu perubahan jenjang atau perbaikan kondisi dari perekonomian yang lemah kearah perekonomian yang lebih baik atau mengalami kemajuan dari sebelumnya. Pengembangan ekonomi lokal perlu diarahkan untuk mendukung perkembangan sektor-sektor ekonomi yang mempunyai potensi menciptakan kesempatan kerja yang luas dan memiliki prospek yang baik dalam meningkatkan kesejahteraan masyarakat di suatu wilayah. Maka dari itu dengan adanya program ekonomi kreatif yang dilakukan diharapkan mampu merubah sedikit demi sedikit perekonomian masyarakat yang ada di kampung Goleah dengan mengadakan inovasi baru untuk menjadikan kampung tersebut memiliki mata pencaharian yang lebih beragam dengan memanfaatkan barang bekas yang nantinya dapat bernliai seni dan bernilai jual atau bernilai ekonomis.

Aspek perekonomian Kampung Goleah RT 01 dan RT 02 RW 02 memiliki permasalahan salah satunya kurang mata pencaharian untuk ibu rumah tangga dan pemuda. Sementara itu, sumber daya manusia di Kampung Goleah sangat berlimpah terutama ibu rumah tangga. Di kampung Goleah sendiri ini banyak sekali ibu-ibu yang bertani dan berkebun di sekitar kampung bahkan tidak sedikit yang bertani hingga keluar kampung. Masyarakat di kampung tersebut hanya memanfaatkan pekerjaan bertani dan berkebun saja. Selama ini pun hasil tani yang dihasilkan oleh masyarakat Goleah hanya di jual sebagai pemasok bahan baku dari sayuran tersebut.

Secara umum perekonomian masyarakat kampung Goleah dapat dikatakan masih standar atau berada pada kelas menengah. Meskipun ada juga beberapa masyarakat yang sudah di atas ratarata. Masyarakat Kampung Goleah masih kurang berinovasi dalam melakukan setiap pekerjaan.Hal ini terbukti tidak sedikit masyarakat hanya mengandalkan pekerjaan bertani dan berkebun saja. Padahal hasil dari pertanian bisa dikembangkan menjadi sesuatu yang bisa bernilai ekonomi.

Berdasarkan hasil analisis lapangan di Kampung Goleah, sebenarnya banyak ibu-ibu dan pemuda yang mampu berpikir secara kreatif untuk membuat karya-karya yang menarik berbagai potensi yang ada di kampung goleah sangat memungkinkan dapat dikembangkan dan dapat mewujudkan home industri oleh karena itu perlu adanya pelatihan masyarakat dalam pembuatan kerajinan tangan dengan melakukan berbagai macam kegaiatan, (1) Pelatihan pembuatan kerajinan tangan berbahan dasar koran bekas (2) Memotivasi masyarakat dalam mewujudkan home industri yang berasal dari pemanfaatan barang bekas.

\section{MATERI DAN METODE}

\section{Materi}

Istilah Ekonomi kreatif berkembang dari konsep modal berbasis kreativitas yang dapat berpotensi meningkatkan pertumbuhan ekonomi di suatu daerah. Menurut Presiden Susilo Bambang Yudhoyono dalam Agung Pascauseno (2014), "ekonomi kreatif merupakan ekonomi gelombang ke-4 yang mana kelanjutan dari ekonomi kreativitas, budaya, serta warisan budaya dan lingkungan." Terdapat pergeseran orientasi gelombang ekonomi dalam sejarah manusia. Dimulai dari perubahan era pertanian ke era industrialisasi, setelah itu terbentuk era informasi yang diikuti dengan penemuan-penemuan bidang teknologi informasi. Pergeseran gelombang ini telah membawa peradaban yang baru dan semakin berkembang bagi manusia.

Ekonomi kreatif adalah suatu konsep untuk merealisasikan pembangunan ekonomi yang berkelanjutan berbasis kreativitas. Pemanfaatan sumber daya yang bukan hanya terbarukan bahkan tidak terbatas yaitu ide, gagasan, bakat atau talenta dan kreativitas. Nilai ekonomi dari suatu produk atau jasa di era kreatif tidak lagi ditentukan oleh bahan baku atau sistem produksi seperti pada era industri, tetapi lebih kepada pemanfaatan kreativitas dan penciptaan inovasi melalui pengembangan teknonogi yang semakin maju. Industri tidak dapat lagi bersaing di pasar global dengan hanya mengandalkan harga atau kualitas saja, tetapi harus bersaing berbasiskan inovasi, kreativitas dan imajinasi. 
Di masa kini, ekonomi kreatif telah menjadi hal penting sebab bersumber pada kreativitas yang merupakan sumber daya terbarukan. Peran ekonomi kreatif ini akan menjadi semakin penting di masa mendatang, terutama pada saat sumber daya yang tidak terbarukan semakin terbatas atau langka. Kreativitas telah dan akan terus mengubah paradigm perekonomian yang biasa terpusat pada keterbatasan (scarcity) menjadi berpusat pada keberlimpahan (abundancy).

Ekonomi kreatif menjadi salah satu konsep untuk pengembangan perekonomian di Indonesia yang mana, Indonesia bisa mengembangkan model ide dan talenta dari rakyat untuk dapat menginovasikan dan menciptakan suatu hal baru. Pola pikir kretaif yang sangat diperlukan untuk tetap tumbuh berkembang serta bertahan di masa yang akan datang.

Tumbuhnya industri kreatif di Indonesia disebabkan adanya krisis global yang berkepanjangan sehingga memunculkan semangat yang lebih dalam menciptakan, mengkreasikan, dan menginovasikan sesuatu dalam menciptakan ide-ide dan karya-karya yang baru. Arief Johari menyatakan bahwa pertumbuhan industri kreatif yang baik di Indonesia belum mampu memberikan pengaruh yang positif dan signifikan bagi Indonesia salah satu penyebabnya adalah "Manajemen Problem" yaitu suatu pemikiran yang menyebabkan adanya pemikiran bahwa sebuah produk yang dihasilkan hanya untuk konsumsi di dalam negeri sehingga hal inilah menyebabkan bahwa Indonesia termasuk pada kategorisasi sebagai negara konsumtif yang potensial secara internasiona. Berdasarkan uraian di atas maka perumusan masalah adalah ekonomi kreatif sebagai suatu solusi mensejahterakan masyarakat dalam meningkatkan tingkat perekonomian.

Dalam hal ini sebuah inovasi sangat diperlukan untuk bisa menciptakan ekonomi kreatif yang di inginkan. Adapun yang dimaksud dengan inovasi adalah sebuah gagasan, produk atau proses yang memiliki potensi untuk digunkan sebagai pemacu daya saing sebuah bangsa, wilayah, industri, organisasi, indivisu atau gabungan dari katagorikatagori ini. Dengan memanfaatkan bahan bekas yang sudah tidak terpakai lalu di inovasikan menjadi sebuah produk yang layak dipasarkan dan layak untuk dihargai.

Inovasi adalah suatu penemuan baru yang berbeda sebelumnya atau dari yang sudah ada atau yang dikenal sebelumnya, orang atau wirausaha yang selalu berinovasi, maka ia dapat dikatakan seorang wirausahawan yang inovatif.
Sedangkan orang yang inovatif selalu berupaya melakukan perbaikan, menyajikan sesuatu yang baru atau unik yang ebrbeda dengan yang sudah ada sebelumnya. Dengan kata lain inovasi (innovation) adalah suatu ide, barang, kejadian, atau metode yang dirasakan atau diamati sebagai suatu hal yang baru bagi seseorang atau sekelompok orang, baik itu berupa hasil discovery maupun invensi. Tujuan diadakan inovasi adalah untuk memecahkan suatu masalah tertentu. Dengan demikian, dapat dikatakan inovasi bersifat subyektif dan spesifik. Sedangkan pengertian inovasi menurut Huberman adalah proses kreatif dalam memilih, mengorganisasikan dan memanfaatkan sumber daya manusia dan materil dalam cara-cara baru atau dan uni yang akan menghasilkan pencapaian lebih tinggi yang telah ditetapkan.

Inovasi ada untuk mendukung terwujudnya suatu ekonomi kreatif yang diinginkan. Tetapi bukan hanya inovasi saja yang dibutuhkan dalam terwujudnya ekonomi kreatif. Hal yang dibutuhkan lainya adalah suatu kreatifitas yang tinggi. Kreativitas tidak sebatas pada karya yang berbasis seni dan budaya namun juga bisa berbasis ilmu pengetahuan dan teknoligi, engineering dan ilmu telekomunikasi. Terdapat 3 hal pokok yang menjadi dasar dari ekonomi kreatif, antara lain kretivitas, inovasi dan penemuan. Kreativitas merupakan sumber daya terbarukan dan tidak akan ada habisnya jika sumber daya manusia keratif Indonesia yang jumlahnya besar dapat berkreasi dan menciptakan nilai tambah yang didukung oleh iklim kondusif.

Kreativitas adalah suatu kemampuan untuk menciptakan sesuatu yang baru yang berbeda dari sebelumnya, baik berupa gagasan atau karya nyata dnegan menggabung-gabungkan unsureunsur yang telah ada sebelumnya. Hal baru disini adalah sesuatu yang belum diketahui oleh yang bersangkutan (masyarakat sekitar), meskipun hal itu merupakan hal yang tidak asing bagi orang lain dan bukan hanya dari yang tidak menjadi ada tetapi juga kombinasi baru dari sesuatu yang sudah ada. Maka oleh karena itu kita harus dapat menjadikan pemahaman masyarakat sekitar mendapatkan pengalaman-pengalaman baru, berimajinasi yang kuat, berinisiatif yang tinggi penuh semangat serta berani dalam mengambil resiko dan berani dalam mengungkapkan pendapat dari keyakinanya.

Kreativitas sendiri merupakan faktor utama dalam terciptanya inovasi baru yang ada, penciptaan karya kreatif dengan memanfaatkan 
inovasi yang sudah ada atau penemuan yang telah ada sebelumnya. Dengan adanya inovasi yang dibarengi dengan kreativitas maka akan mendorong peningkatan produktivitas yang bernilai jual tinggi. Dengan kata lain dalam mewujudkan ekonomi kreatif yang di inginkan maka inovasi dan kreativitas yang tinggi sangat dibutuhkan. Adanya inovasi yang baru dibarengi dengan kreativitas yang tinggi dari setiap individu membuat kegiatan ekonomi kreatif akan berjalan dengan lancar.

Menurut Dep. Dikbud penyusun KBBI, Limbah adalah sisa proses produksi atau bahan yang tidak mempunyai nilai atau tidak berharga untuk maksud biasa atau utama pembuatan atau pemakaian. Menurut Peraturan Pemerintah No 18 Tahun 1999, limbah adalah sisa suatu usaha dan atau kegiatan. Limbah adalah buangan yang kehadirannya pada saat dan tempat tertentu tidak dikehendaki lingkungannya karena tidak mempunyai nilai ekonomi. Bahan ini dirumuskan sebagai bahan dalam jumlah relative sedikit tapi mempunyai potensi mencemarkan atau merusak lingkungan kehidupan dan sumber daya.

Limbah dapat dibedakan menjadi sampah organik sampah anorganik dan sampah berbahaya. Sampah organik atau sampah basah adalah sampah yang berasal dari makhluk hidup, samah oranik juga dikatagorikan sebagai jenis sampah yang dapat diuraikan oleh alam atau secara alami dalam waktu yang cepat, seperti sisa daun-daunan, sisa sayuran, kertas dan lain-lain. Sampah anorganik atau kering adalah sampah yang tidak dapat terdegradasi atau tidak dapat diuraikan atau dihancurkan dengan cepat oleh alam, seperti karet, plastik, logam dan kaca. Sedangkan sampah berbahaya adalah jenis sampah yang berbahaya bagi manusia. Contoh sampah berbahaya antara lain adalah baterai, jarum suntuk, kimbah racun kimia, limbah nuklir dan lain sebagainya, limbah sampah berbahaya juga memerlukan pengangan khusus.

Dalam kegiatan mewujudkan ekonomi kreatif untuk masyarakat kampung Goleah, maka dimanfaatkanlah salah satu jenis limbah sampah yaitu sampah organik seperti kertas koran. Kertas koran berdasarkan jenisnya termasuk ke dalam limbah organik. Menurut Dep. Dikbud penyusun KBBI, kertas adalah bahan lembaran di buat dari bubur rumput, jerami, kayu dan sebagainya. Kertas ialah sebuah benda yang sangat tipis yang terbuat dari serat-serta alamiah biasanya batang pohon dan lain-lain yang berevolusi seiring pergantian sebuah peradaban dari zaman. Maka dapat kertas koran yang sudah tidak terpakai dapat dikatagorikan sampah organik karena terbuat dari serat-serta alamiah yang dimanfaatkan untuk mencetak surat kabar koran.

Dari informasi yang terbaru bahwa keuntungan terbesar dari daur ulang kertas adalah konservasi lingkungan. 90 persen dari semua kertas bekas dan sekitar 35 persen dari pohon-pohon di dunia adalah untuk memproduksi kertas. Daur ulang kertas koran menyimpan jumlah yang sama dengan pencetakan kertas fotokopi. Daur ulang kertas di dunia akan menghemat 40 juta hektar (162.000 kilometer persegi) lahan hutan. Manfaat lingkungan kedua utama dari kertas daur ulang berkurang polusi. America Serikat Environmental Protection Agency (EPA) memperkirakan bahwa pembuatan kertas menggunakan cara daur ulang.

Kerajinan tangan berbahan dasar koran bekas sangat mungkin diberikan kepada ibu rumah tangga serta para pemuda kampung Goleah sebagai suatu inovasi baru dalam bidang ekonomi. Dengan mengambil manfaat dari limbah koran tersebut ibu rumah tangga dan pemuda dapat berkreasi dengan berbagai macam bentuk yang dinginkan. Dalam kegiatan pelatihan kerajinan tangan berbahan dasar koran ini kami menggunakan metode demontrasi dan praktek secara langsung.

\section{Penyusunan Kegiatan Program}

Kajian teori tersebut untuk mendukung penyusunan program kerja di bidang ekonomi untuk mengatasi permasalah-permasalah ekonomi di Kampung Goleah Desa Sukagalih. Berikut program kerja yang dilaksanakan terdapat pada Tabel 1.

Tabel 1. Program Kerja Kegiatan Pengabdian.

\begin{tabular}{|l|l|l|}
\hline NO & Program Kerja & Uraian Program \\
\hline 1 & $\begin{array}{l}\text { Pelatihan Pembuatan } \\
\text { Kerajinan Tangan } \\
\text { Berbahan Dasar } \\
\text { Koran. }\end{array}$ & $\begin{array}{l}\text { Pelatihan } \\
\text { kerajinan tangan } \\
\text { untuk } \\
\text { menciptakan } \\
\text { lapangan kerja } \\
\text { baru r serta } \\
\text { penghasilan } \\
\text { tambahan bagi ibu } \\
\text { rumah tangga } \\
\text { dengan } \\
\text { memanfaatkan } \\
\text { barang bekas }\end{array}$ \\
\hline
\end{tabular}




\begin{tabular}{|l|l|}
\hline & $\begin{array}{l}\text { seperti koran } \\
\text { bekas. }\end{array}$ \\
& \\
\hline
\end{tabular}

\section{HASIL DAN PEMBAHASAN}

\section{Hasil}

\section{Letak Geografis}

Desa Sukagalih merupakan salah satu Desa di wilayah Kecamatan Megamendung Kabupaten Bogor, dengan luas wilayah 247,220 yang terbagi menjadi 2 Dusun, 4 Rukun Warga (RW) dan 20 Rukun Tetangga (RT) dengan kepadatan penduduk 0.31 per Kilometer. Dan merupakan daerah dataran tinggi dengan ketinggian dari permukaan laut $900 \mathrm{mdpl}$ dengan suhu udara $27^{\circ}$ $\mathrm{C}-33^{0} \mathrm{C}$. Jarak tempuh dari pusat pemerintahan dalam melaksanakan hubungan dan komunikasi kerja dengan pemerintahan diatas secara berjenjang sebagai berikut : Dengan Kantor Kecamatan berjarak: $5 \mathrm{Km}$; Dengan Ibu Kota Kabupaten berjarak: $25 \mathrm{Km}$; Dengan Ibu Kota Propinsi berjarak: $120 \mathrm{Km}$. Dengan memilik batas wilayah sebagai berikut: Sebelah selatan berbatasan dengan PTPN Nusantara VIII; Sebelah utara berbatasan dengan Desa Sukarya; Sebelah barat berbatasan dengan Desa Sukaresmi; Sebelah timur berbatasan dengan Desa kuta.

Desa Sukagalih berada pada jalur pariwisata untuk menuju jalur Taman Safari Indonesia, Puncak Cisarua bahkan Cianjur dan Bandung. Dengan begitu luasnya Desa Sukagalih dan terpisah-pisah jarak yang begitu jauh antara kampung satu dengan kampung yang lainnya. Serta belum adanya kendaraan umum menuju Desa Sukagalih, hal itu menjadikan Desa Sukagalih belum dikatagorikan Desa yang telah maju. Desa Sukagalih sebagian besar merupakan persawahan dan perkebunan, pemukiman (rumah warga serta villa-villa) dan banyak pula yang membuka sentra perdagangan karena berada pada jalur alternative.

\section{Jumlah Penduduk}

Desa Sukagalih dapat dikatakan desa dengan kepadatan penduduk yang cukup padat terdapat 3.132 jumlah kepala keluarga yang sudah tercatat.
Dapat dilihat pada tabel 1 tentang jumlah penduduk Desa Sukagalih :

Tebel 2. Jumlah Penduduk Desa Sukagalih

\begin{tabular}{|c|c|c|c|}
\hline KELOMPOK & JUMLA & H JIWA & \\
\hline UMUR & $\begin{array}{l}\text { LAKI- } \\
\text { LAKI }\end{array}$ & PEREMPUAN & JUMLAH \\
\hline $0-4$ & 519 & 486 & 1.005 \\
\hline $5-9$ & 510 & 516 & 1.026 \\
\hline $10-14$ & 521 & 420 & 941 \\
\hline $15-19$ & 509 & 411 & 920 \\
\hline $20-24$ & 456 & 419 & 875 \\
\hline $25-29$ & 276 & 438 & 714 \\
\hline $30-34$ & 260 & 240 & 500 \\
\hline $35-39$ & 248 & 220 & 468 \\
\hline $40-44$ & 248 & 200 & 448 \\
\hline $45-49$ & 168 & 137 & 305 \\
\hline $50-54$ & 147 & 131 & 278 \\
\hline $55-59$ & 126 & 116 & 242 \\
\hline $60-64$ & 126 & 129 & 255 \\
\hline $65-69$ & 92 & 87 & 179 \\
\hline 70 -atas & 88 & 82 & 170 \\
\hline JUMLAH & 4.294 & 4.032 & 8.326 \\
\hline
\end{tabular}




\section{Jumlah Penduduk Berdasarkan Agama dan Kepercayaannya}

Desa Sukagalih dapat dikatakan desa yang memiliki penganut agama islam terbesar. Agama memegang peranan penting dalam kehidupan Desa Sukagalih khususnya Kampung Goleah, Dapat dilihat pada Tabel 3 :

Tabel 3.Jumlah pemeluk agama dan kepercayaanya warga Desa Sukagalih.

\begin{tabular}{|l|l|l|}
\hline NO & Agama & Jumlah \\
\hline 1 & Islam & 8.308 orang \\
\hline 2 & Katholik & 15 orang \\
\hline 3 & Protestan & - \\
\hline 4 & Hindu & 3 \\
\hline 5 & Budha & - \\
\hline 6 & Konghuchu & - \\
\hline 7 & Aliran & - \\
\hline
\end{tabular}

\section{Jenis Mata Pencaharian Penduduk}

Jenis pekerjaan atau mata pencaharian masyarakat Desa Sukagalih sangat beragam, dapat dilihat pada Tabel 4 :

Tabel 4. Mata Pencaharian Penduduk Warga Desa Sekagalih.

\begin{tabular}{|l|l|l|}
\hline NO & Jenis Mata Pencaharian & Jumlah \\
\hline 1 & Petani & 1.103 \\
\hline 2 & Pengusaha & 37 \\
\hline
\end{tabular}

\begin{tabular}{|l|l|l|}
\hline 3 & Pengrajin & 2 \\
\hline 4 & Buruh Industri & 92 \\
\hline 5 & Buruh Bangunan & 338 \\
\hline 6 & Buruh Perkebunan & 159 \\
\hline 7 & Pedagang & 126 \\
\hline 8 & Pengemudi & 258 \\
\hline 9 & Pegawai Negara Sipil & 24 \\
\hline 10 & TNI/POLRI & 2 \\
\hline 11 & Pensiunan (PNS/TNI/POLRI) & 126 \\
\hline
\end{tabular}

\section{Pembahasan}

Pelaksanaan Program Pendampingan dan Pembuatan Kerajinan Tangan Berbahan Dasar Koran

Keadaan ekonomi erat kaitannya dengan mata pencaharian masyarakat dan merupakan jantung dari kehidupan manusia, karena setiap orang senantiasa mendapatkan pekerjaan sesuai dengan bidang dan keahliannya masing-masing. Jenis sarana ekonomi yang ada di kampung Goleah adalah berwirausaha membuka warung berskala kecil. Selain itu sarana ekonomi yang menjadi tulang punggung ekonomi masyarakat adalah menjadi penjaga villa-villa yang ada di sekitar kampung Goleah. Keadaan ekonomi masyarakat Kampung Goleah masih rendah. Sehingga sangat perlu diberikan pemahaman yang akan mempengaruhi jenis pekerjaannya. Salah satu faktor yang akan mempengaruhi jenis pekerjaan seorang individu adalah minat belajar yang tinggi serta wawasan yang luas seputar kewirausahaan. Oleh karena itu kita harus memberdayakan masyarakat yang ada. Yang dimaksud dengan pemberdayaan masyarakat adalah memampukan dan memandirikan masyarakat terutama dari kemiskinan yang ada dan keterbelakangan atau kesenjangan atau keberdayaan.

Pengadaan pendampingan dan pembuatan kerajinan tangan berbahan dasar koran melalui pelatihan masyarakat kampung Goleah Desa 
Sukagalih dilaksanakan berdasarkan observasi dan data valid bahwa masyarakat Goleah RT 01 dan 02 RW 02 ini khususnya untuk ibu-ibu sebanyak $80 \%$ adalah buruh tani dan sisanya sebanyak $20 \%$ adalah ibu rumah tangga.

Keadaan ekonomi masyarakat di Desa Sukagalih masih rendah khususnya Kampung Goleah. Sehingga perlu dilakukan pemahaman yang mempengaruhi jenis pekerjaaanya. Kampung Goleah sendiri tidak mempunyai ciri khusus selain dari perkebunannya. Juga tidak terdapat home industri yang bisa memanfaatkan waktu luang dari ibu-ibu kampung Goleah tersebut. Dimaksudkan untuk membuat ciri khas baru untuk Kampung Goleah itu sendiri dengan sebuah gerakan kreatifitas warga dalam ekonomi kreatif. Dengan memanfaatkan bahan bekas yaitu koran kami mengadakan pelatihan mendaur ulang koran bekas menjadi produk-produk dengan berbagai macam bentuk yang mempunyai nilai seni yang tinggi, nilai fungsi serta nilai ekonomis.

Dahulu fungsi koran setelah dibaca orang sering mengabaikan koran tersebut, bahkan membuangnya. Jika koran itu diabaikan maka lama-kelamaan akan menumpuk dan mengotori rumah. Kini koran bekas yang awalnya hanya mengotori rumah itu dapat masyarakat olah menjadi barang-barang yang memiliki fungsi sehingga dipakai serta mempunyai nilai seni dan nilai ekonomi yang cukup tinggi. Kerajinan tangan berbahan dasar koran bekas ini dapat menjadi sebuah produ yang berbentuk piring, mangkuk, tempat jarum, tempat pensil, vas bunga, keranjang buah, keranjang minuman dan lain sebagainya. Dengan kata lain alasan dilakukannya kegiatan pelatihan mendaur ulang kertas koran menjadi sebuah kerajinan tangan adalah agar masyarakat kampung goleah dapat meminimalisis pencemaran lingkungan yang dewasa ini semakin bertambah parah dan lebih mencintai lingkungan sekitar kita.

Dari kegiatan pelatihan daur ulang kertas koran bekas dan dimanfaatkan untuk kehidupan sehari-hari fakta yang didapatkan adalah koran bekas selain dapat didaur ulang koran bekas juga dapat mengurangi pencermaran lingkungan. Dan dapat pula diartikan bahwa daur ulang adalah salah satu strategi dari suatu pengelolaan sampah padat yang terdiri atas kegiatan pemilahan, pengumpulan, pemerosesan, pendistribuan dan pembuatan produk atau material bekas pakai.

Pada kegiatan tersebut, kami bekerja sama dengan Bapak H. Brian Wiryawan selaku pemilik Rumah Koran "Craft Sebelas Kopi” yang bertempat tinggal di Pabuaran Cibinong Bogor. Dengan pelatihan dan pembekalan materi yang diberikan oleh Bapak H. Brian Wiryawan kami bisa mengaplikasikannya langsung kepada masyarakat Kampung Goleah Desa Sukagalih.

Tepatnya Kamis, 09 Agustus 2018 kami mengundang ibu-ibu rumah tangga kampung goleah untuk bisa mengikuti pelatihan pembuatan kerajinan tangan dari bahan bekas Koran yang bertempatkan di PAUD Darul As Sulaha'I. Pendampingan pun dilakukan dengan memberikan materi dan arahan tentang kerajinan tangan dari koran tersebut kepada ibu-ibu yang mengikutinya.

Kegiatan pelatihan dan pembuatan kerajinan tangan ini dihadiri oleh 25 orang ibu rumah tangga yang berasal dari 2 RT yaitu RT 01 dan RT 02 Kampung Goleah. Pelatihan kerajinan tangan ini dilaksanakan sebanyak 2 kali, yaitu pada hari Kamis, 09 Agustus 2018 dan hari Rabu, 15 Agustus 2018.

Adapun langkah-langkah yang kami lakukan dalam berlangsungnya kegiatan pelatihan ekonomi kreatif kerajinan tangan berbahan dasar koran bekas adalah sebagai berikut :

\section{Sosialiasi}

Langkah pertama yang dilakukan untuk mengadakan pelatihan kerajinan tangan berbahan dasar Koran bekas adalah sosialisasi kepada ibuibu rumah tangga kampung Golaeh rt 01 dan rt 02 dengan melalui forum pengajian ibu-ibu yang diadakan setiap minggu, selasa dan kamis pada minggu pertama.

\section{Koordinasi}

Langkah kedua yang kami lakukan adalah melakukan koordinasi dengan ketua rt setempat perihal tempat untuk pelatihan yang akan diadakan di minggu ke-2. Koordinasi berjalan lancar sehingga mendapatkan perizinan PAUD Darul Assulaha'I untuk kegiatan pelatihan kerajinan tangan berbahan dasar koran bekas.

\section{Pelatihan hari pertama}

Setelah memasuki minggu ke-2, tepatnya pada hari Kamis, 09 Agustus 2018 pelatihan hari pertama diadakan di PAUD Darul Asulaha'I dengan diikuti oleh 25 orang ibu rumah tangga di rt 01 dan rt 02. Adapun langkah yang dilakukan untuk pelatihan di hari pertama yaitu sebagai berikut : Menyiapkan alat dan bahan dibutuhkan seperti: Sapu Lidi; Koran; Gunting; Cutter; Lem fox; Kuas; Cetakan gelas, piring,ember, vas bunga; Cat kayu; Semprotan obat nyamuk yang sudah tidak terpakai. 
Memberikan materi tentang entrepreneur, manfaat dari berwirausaha, dan peluang- peluang usaha untuk memotivasi para ibu rumah tangga dalam pemanfaatan barang bekas yang bernilai ekonomi bagi peningkatan produktivitas jiwa entrepreneur juga memberikan panduan tentang cara pembuatan kerajinan tangan berbahan dasar koran bekas.

Selanjutnya adalah memasuki kegiatan pelatihan kerajinan tangan berbahan dasar koran, adapun langkah- langkah pembuatan kerajinan tangan adalah :

a. Lipat Koran menjadi beberapa bagian dengan lebar $8 \mathrm{~cm}$ dan panjang $4 \mathrm{~cm}$.

b. Setelah koran dilipat, koran digunting dengan rapi.

Gambar 1. Lipatan Koran

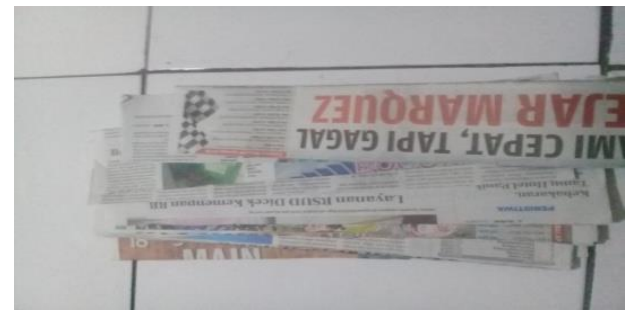

c. Lalu koran yang telah digunting tersebut dilinting menggunakan lidi yang telah di sediakan. Koran dilinting menjadi sebuah lintingan yang kecil, arena dalan membuat sebuah kerajinan tangan berbahan dasar koran bekas yang menggunakan sistem linting ini hal pertama yang harus diperhatikan adalah lintingan koran haruslah di linting sekecil mungkin. Jika lintingan koran besar maka akan mempengaruhi proses penganyaman kerajinan tangan koran tersebut.

Gambar 2. Lintingan Koran

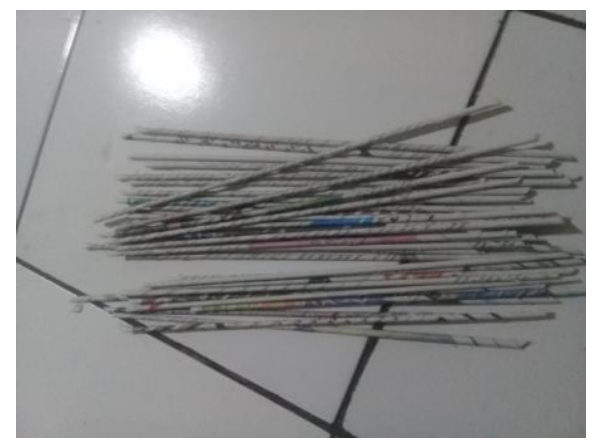

d. Setelah lintingan koran dirasakan sudah cukup banyak. Lintingan Koran tersebut di susun sehingga menjadi satu pola dasar. Dapat dilihat pada Gambar 3 adalah contoh pola dasar dalam menganyam kerajinan tangan koran ini. Apapun cetakannya pola dasar dalam penganyamannya tetap sama selama bentuk yang digunakan adalah lingkaran.

Gambar 3. Anyaman Koran

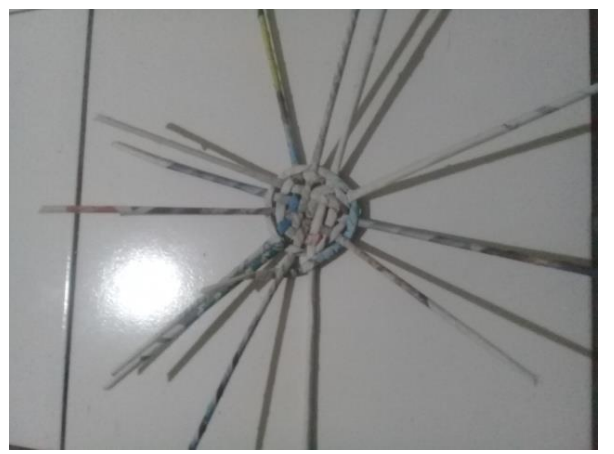

e. Langkah selanjutnya adalah siapkan cetakan yang diiinginkan, setelah pola dasar penganyaman telah siap maka anyam lintingan koran mengikiti bentuk cetakan yang kita inginkan.

Gambar 4. Cetakan Anyaman Koran

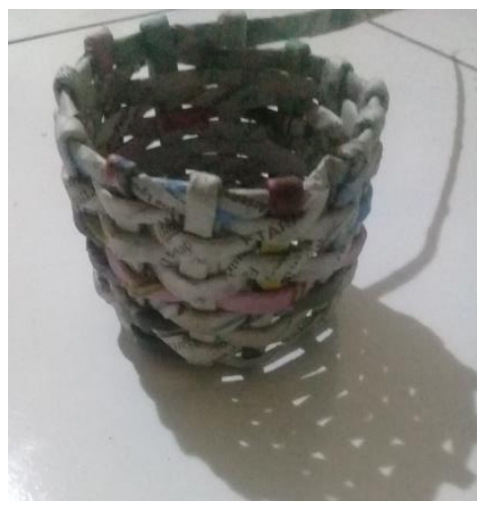

f. Setelah lintingan koran membentuk produk yang diinginkan, maka langkah selanjutnya adalah mengoleskan lem fox pada seluruh lintingan koran secara merata. Fungsi dari mengoleskan lem fox adalah agar produk yang kita buat menjadi kuat, juga agar menutipi celah antar lintingan yang kurang rapat.

g. Koran atau produk yang telah dioleskan lem fox harus dijemur hingga mongering dibawah sinar matahari. Lama pengeringan sekitar 1-2 jam tergantung dari besar produk koran itu sendiri.

h. Produk koran yang telah setengah jadi dibawa masing-masing oleh para ibu-ibu dengan catatan minggu kedua pelatihan produk koran yang telah dibuat tersebut harus dibawa kembali untuk dilakukan finishing. 


\section{Pelatihan kedua}

Pelatihan hari kedua dilaksanakan Rabu, 15 Agustus 2018 di PAUD Darul Asulaha'I dengan melanjutkan kegiatan pelatihan dipertemuan pertama yaitu sebagai berikut :

a. Langkah pertama yang dilakukan dengan menyiapkan cat kayu. Cat kayu yang digunakan dalam kegiatan pelatihan dicampurkan dengan sedikit air agar tidak terlalu kental.

b. Produk koran yang telah dibuat oleh para ibu-ibu di kumpulkan untuk di cat.

c. Proses pengecatan tidak menggunakan kuas tetapi menggunakan sistem sempot. Sistem sempot ini menggunakan obat nyamuk bekas yang tidak terpakai. Dengan menggunakan sistem semprot ini dimaksudkan agar cat yang dihasilkan lebih mengkilat dan lebih merata.

d. Setelah proses pengecatan, produk koran kembali dijemur dibawah sinar matahari hingga mengering secara merata. Lama pengeringan sekitar 3-4 jam tergantung dari besar produk yang dihasilkan.

\section{Produk Koran yang di Hasilkan}

Adapun hasil dari kegiatan pelatihan kerajinan tangan koran mendapatkan berbagai macam produk koran yang telah dibuat oleh para ibu rumah tangga yaitu :
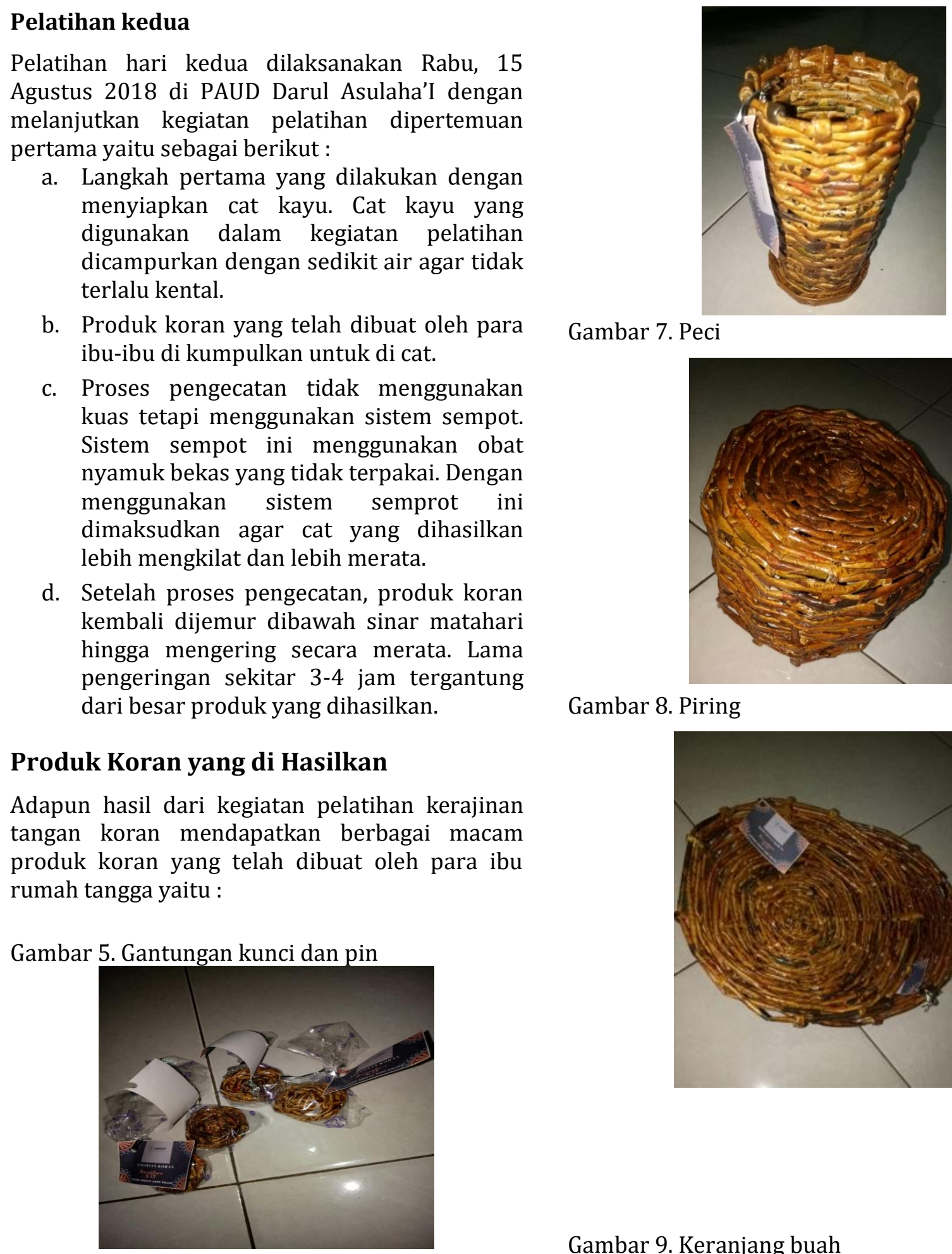

Gambar 7. Peci

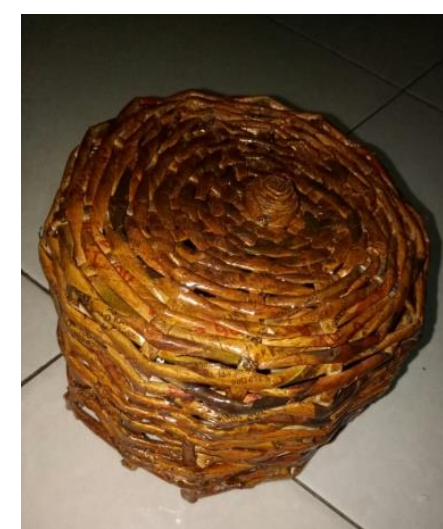

Gambar 8. Piring

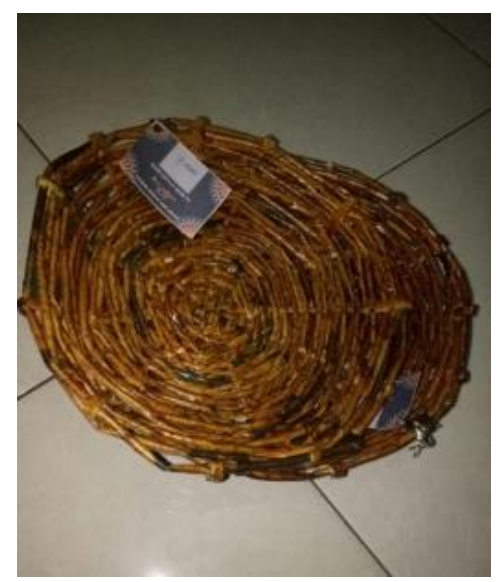

Gambar 9. Keranjang buah

Gambar 6. Tempat pengsil 


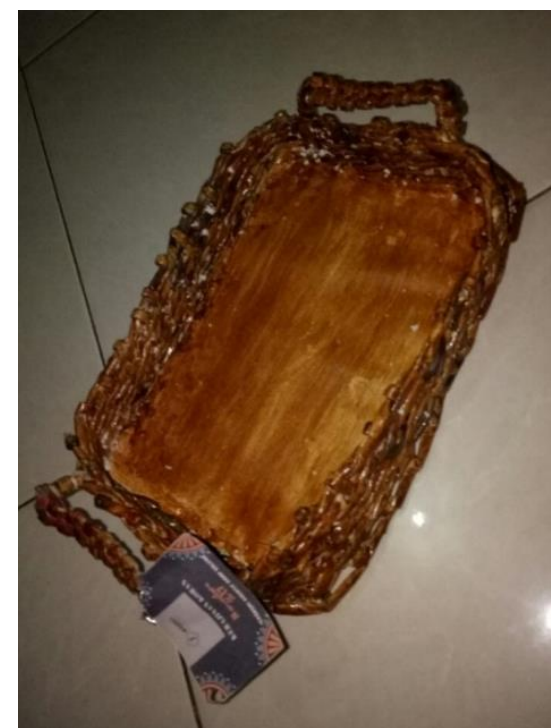

Gambar 10. Mangkuk

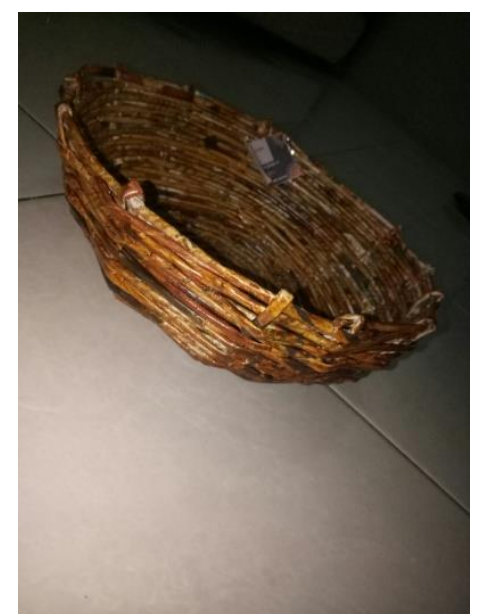

Hasil yang didapatkan ketika mengikuti pelatihan pembuatan kerajianan tangan berbahan dasar koran bekas ini adalah :

a. Waktu luang yang dimiliki ibu rumah tengga kampung goleah menjadi lebih bermanfaatkan dan lebih efektif karena membuat kerajinan tangan dari koran ini mudah untuk dilakukan di rumah.

b. Memanfaatkan barang bekas yaitu koran. Sehingga koran yang tak terpakai bisa dialihkan fungsinya menjadi sebuah produk yang memiliki nilai seni.

c. Kerajianan tangan dari koran ini bernilai seni dan juga bernilai ekonomis.

\section{Faktor Pendukung dan Penghambat}

Faktor pendukung kegiatan pelatihan kerajinan tangan berbahan dasar koran bekas ini terlaksanakan dengan baik berkat didukung dari berbagai faktor, yaitu :

\section{Komitmen peserta pelatihan}

Peserta pelatihan yang terdiri dari ibu rumah tangga Kampung Goleah RT 01 dan RT 02 sangat antusias dan sangat bersemangat dalam mengikuti pelatihan dari awal hingga akhir. Begitu pula pada saat penugasan dimana para ibu rumah tangga dituntut untuk membuat kerajinan tangan koran sendiri, para ibu rumah tangga sangat bersemangat dan tidak segan untuk bertanya seputar kerajinan tangan dari koran.

\section{Faktor Penghambat}

Faktor penghambat dalam kegiatan pelatihan kerajinan tangan berbahan dasar koran bekas ini terkendala masalah keterbatasan waktu. Jumlah tatap muka sebanyak dua kali dirasakan kurang efektif dalam kegiatan pelatihan ini. Dapat dikatakan antusiasme para ibu rumah tangga merasa waktu pelatihan masih terlalu singkat karena harus berakhir di saat para ibu rumah tangga telah memahami materi kerajinan tangan. Walaupun sebagaian besar para ibu rumah tangga sudah dapat membuat produk kerajinan tangan yang sudah cukup baik dan bagus.

\section{KESIMPULAN DAN IMPLIKASI}

\section{Kesimpulan}

Perekonomian masyarakat kampung goleah masih perlu untuk ditingkatkan. Walaupun perekonomian masyarakat kampung Goleah masih dapat dikatakan standar, tetapi tingkat perekonomian kampung Goleah tersebut dapat ditingkatkan melalui kegiatan ekonomi kreatif. Dapat dilihat dari segi geografis kampung Goleah berada pada kawasan yang stategis dikelilingi oleh beberapa taman hiburan keluarga seperti Taman Matahari, Taman Safari dan Puncak. Hal ini dapat dimanfaatkan untuk menggali potensi masyarakat di bidang ekonomi dan dengan adanya kegiatan pelatihan kerjainan tangan berbahan dasar koran bekas ini diharapkan dapat menjadi wadah bagi masyarakat untuk bisa memasarkannya sebagai sebuah oleh-oleh atau buah tangan khas Kampung Goleah.

Kepedulian masyarakat akan barang bekas khususnya koran bekas akan semakin meningkat. Dengan adanya kegiatan pelatihan pembuatan kerajianan tangan berbahan dasar koran bekas ini diharapkan fungsi koran yang telah dibaca dan tidak terpakai akan beralih fungsi menjadi suatu produk yang bernilai seni dan bernilai ekonomis. 
Antusiasme yang diberikan oleh ibu rumah tangga kampung goleah sangat baik.

\section{Implikasi}

Adapun hasil pengabdian di Kampung Goleah Desa Sukagalih, memberikan implikasi antara lain :Perlunya dukungan dari setiap pihak seperti masyarakat sekitar serta perangkat desa. Ibu rumah tangga kampung goleah diharapkan bisa membantu perekonomian keluarga dengan melalui ekonomi kreatif. Setelah mengikuti kegiatan pelatihan kerajinan tangan koran para ibu rumah tangga diharapkan bisa mencari celah bisnis yang ada dan dapat mengembangkannya sendiri di rumah masing-masing.

\section{DAFTAR PUSTAKA}

Aldy Purnomo, Rochmat. 2016. Ekonomi Kreatif Pilar Pembangunan Indonesia. Surakarta : Ziyad Visi Media.
Arief Johari, Globalisasi dan Dampak Desain Serta Relasinya Terhadap Industri Kreatif, Magister Desain ITB 27111006

Astuti, Sri. 2012. Pemanfaatan Limbah Kertas Koran Sebagai Bahan Utama Pembuatan Tas dan Sandal di "Dluwang Art" Sinduadi Sleman Yogyakarta [skripsi]. Yogyakarta.Universitas Negeri Yogyakarta.

Humaidi, Ismail. 2015. Peningkatan Perekonomian Masyarakat Melalui Industri : Studi Terhadap Masyarakat di Sentra Industri Kecil di Desa Tutul Kecamatan Balung Kabupaten Jember Jawa Timur [skripsi].Yogyakarta. Universitas Negeri Sunan Kalijati Yogyakarta.

Kristiawan, Muhammad, dkk. 2018. Inovasi Pendidikan (Cetakan Pertama). Ponorogo : WadePrint.

Tim Penulis Bekreaf. 2016. Sistem Ekonomi Kreatif Nasional (Panduan Pemeringkatan Kabupaten/Kota Kreatif). Deputi Infastruktur Badan Ekonomi Kreatif. 